\title{
Goats: Imperatives for Developing the Champions of the Poor and the Landless
}

Devendra $C^{*}$

Consulting Tropical Animal Production Systems Specialist, 130A Jalan Awan Jawa, Kuala Lumpur, Malaysia

*Corresponding author: Dr. Devendra C, PhD, DSc, Consulting Tropical Animal Production Systems Specialist, $130 \mathrm{~A}$ Jalan Awan Jawa, 58200 Kuala Lumpur, Malaysia, Tel: 603-7987-9917; E-mail: cdev@pc.jaring.my

Rec date: Aug 22, 2014, Acc date: Nov 21, 2014, Pub date: Nov 23, 2014

Copyright: (C) 2014 Devendra C. This is an open-access article distributed under the terms of the Creative Commons Attribution License, which permits unrestricted use, distribution, and reproduction in any medium, provided the original author and source are credited.

\section{Introduction}

Animal-agriculture production is pivotal for food security, economic growth and rural prosperity. In Asian agriculture, the goat is revered as the first animal to be domesticated, and has an important economic and ecological niche. It is very widely distributed, but the preferred environment is the semi-arid to arid agro-ecological zones (AEZs) [1] such as West Asia and North Africa (WANA) region [2], within-country in Rajasthan in India, Baluchistan in Pakistan, Harare in Zimbabwe, Chihuahua and San Louis Portosi in Mexico The value of goats increases in relation to its contributions, capacity to adapt to different rainfed less-favored areas (LFAs), cope with the effects of climate change, and respond to market opportunities and human dietary changes [3].

\section{Inherent Attributes of Goats}

Goats have many unique inherent attributes and features as follows:-

- The small size of goats is significant, for many imputale reasons of socio-economic, managerial, biological traits food security, socioeconomic relevance, survival, and development for productivity enhancement (Figure 1).

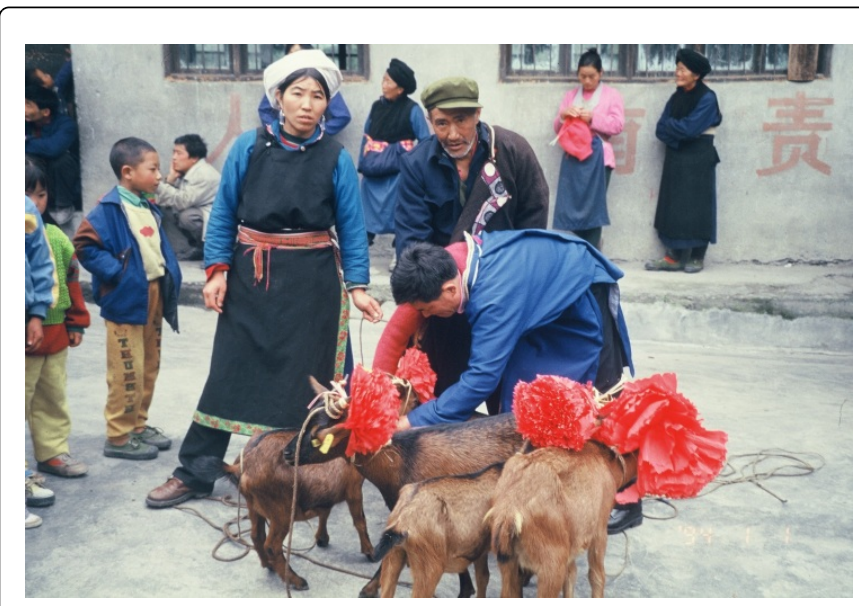

Figure 1: Note in this photo from the Xian province in China, that three generations are involved: young boy, his parents, and behind them the grandfather (C Devendra).

- Irrespective of location and quantum of milk used, more people drink goat milk than from any other species in the world
- Empowerment of women is central to women's control and use of productive assets, bargaining power, increased participation in social and credit programmes and networking

- The capacity to adapt explains the wide global distribution of 1128 million goats in 2013 across all AEZs, from the deserts to the humid regions and environmental interactions. Goats account for about $36 \%$ of the total world population of grazing animals. They can be used as an entry point for the development of rainfed LFAs

- The high concentrations and the presence about $41.5 \%$ of the goat population found in the semi-arid/arid (AEZs) coincide with extreme poverty, the poorest of the poor who live a life of continuing syndrome of poverty-adaptation-fragile lives-little hope- low life expectancy complex

- Malaysia and Indonesia together have the largest land area of about 8.4 million ha under oil palm. The native undergrowth has a $72-93$ $\%$ herbage mixture of grasses, legumes, shrubs and ferns which are palatable. These are attractive to the inquisitive feeding habits of goats and their inherent ability to use fibrous feeds more efficiently [4]. The situation favors the development underestimated silvopastoral systems [5]

- Carbon is sequestered in agroforestry or silvopastoral systems.

- Additionally, goat manure and urine provide precious nutrients for microorganisms the soils, especially in the LFAs.

The development of agriculture and livestock assets is a most significant contribution by goats to the livelihoods of millions of small farmers and the landless. In India, the late Mahatma Gandhi championed the ownership of goats for socio- economic benefits, nutritional security, and the value of goat milk for good health, especially for the under-privileged and the malnourished rural poor.

\section{Current Trends in $\mathrm{R}$ and $\mathrm{D}$}

An objective critique of research undertaken and their implications hitherto reflect some deep concerns inter alia as follows :-

- Most developing countries do not accord adequate policy and priority funding to recognise and maximize potential productivity

- Research thrusts continue to emphasise disciplines devoid of sustainability issues

- Fundamental and applied efforts are the norm but more adaptive, interdisciplinary on-farm $\mathrm{R}$ and $\mathrm{D}$, including the effects of climate change are scarce

- The application of methodologies and yield-inducing R and D in whole -farm systems in response to needs and priorities is unclear and weak, and

- Projects are inadequate that specifically focus on pro-poor initiatives that enhance livelihoods of small farmers and the landless are inadequate. 
Page 2 of 3

\section{Transforming Agriculture}

Technologically driven transformation is important to increase the productivity and contribution from goats. These include the following:-

\section{Changing the mind set}

(a) Ensure detailed identification of the major constraints and priorities for resolution

(b) Determine yield-inducing technologies using systems perspectives and farm needs

(c) Facilitate community-based participation to demonstrate impacts, and

(d) Promote efficient management of natural resources [6], recognizing community participation and traditional knowledge, in the context of envionmentally sustainable production systems.

\section{Importance of interdisciplinary research}

A policy framework is very important and includes the following inter alia:-policy through advocacy, on gender, $\mathrm{R}$ and $\mathrm{D}$ investment, and through direct government action.

\section{Improved value chains}

Improved and efficient value chains are essential to support the marketing of clean goat meat. Marketing and transaction costs are major constraints for small farmers and need to be reduced. A significant development pathway for small farmers and the landless are intensification of production systems, specialization, commercialization and more aggressive participation in market competitiveness (Table 1).

\begin{tabular}{|l|l|}
\hline Region & Potential export areas \\
\hline Australia and New Zealand & Middle East region: South East Asia \\
\hline South East Asia & Middle East region \\
\hline South Asia & Middle East region \\
\hline North Africa & Middle East region \\
\hline West and East Africa & North Africa \\
\hline South America & Central America \\
\hline Caribbean & Southern USA \\
\hline
\end{tabular}

Table 1: Potential export target areas around the globe

With improved production systems and yield inducing technologies, challenging opportunities exist for tapping into large scale goat meat markets. The first priority of course is to maximize domestic production to meet national needs in intensive and specialized systems. This will also promote trade within- and between regions, reflected very broadly below, notwithstanding addressing issues of logistics and trans-boundary diseases. These challenges and opportunities can pave the way for a vibrant export trade

\section{$R$ and $D$ Priorities and a Vision for the Future}

Improved agriculture and potential increased productivity will need assertive a number of key $\mathrm{R}$ and $\mathrm{D}$ investigations inter alia:-

Wider use of indigenous breeds, especially the "improver breeds" and indigenous knowledge. Examples of improver breeds: Barbari and Malabar (India) and Bach Thou (Vietnam)

Aggressive priority development of the rainfed areas or LFAs needs urgent attention and donor funding

Generate more improved understanding of the available information is necessary on various aspects of the value chains e.g. methods of transportation, types of markets (assembling, distribution markets and weekly markets), characteristics of marketing systems; marketing channels and outlets etc.

(iv) intensify gender equality and women's empowerment through education and training, participation in project formulation and contribution, improved understanding of the dynamics of the ownership and decision making, strengthen local women's organisations, and gender equality in livestock services and activities [7], and

(v) Strategic partnerships with Asia can greatly enrich and complement $\mathrm{R}$ and $\mathrm{D}$, and promote more rapid progress in Africa and Latin America [8].

\section{Conclusions and the Continuing Dilemma}

A predominant feature about the dominance of goats in the developing world is that there is natural population increase, and the species has ensured conclusion's survival in the most poverty-stricken areas. The justification for priority development in the future is associated with the following:-

- Improved agricultural technologies in the past came from the developed countries, notably the USA, Australia, New Zealand, England, and South Africa. Developing countries will therefore have to be more self-reliant to pursue $\mathrm{R}$ and $\mathrm{D}$ using locally available inexpensive inputs that are appropriate to the local environment.

- Community-based $\mathrm{R}$ and $\mathrm{D}$ that builds on indigenous resources and the meagre assets of the poor are more likely to be adopted than from elsewhere.

- Donor communities have provided negligible funds for $\mathrm{R}$ and $\mathrm{D}$ on goats. Many of the projects have tended to be top down, without regard to community-based partnerships.

- However, dairy production in goats has greatly benefitted from the developed countries, notably the USA, France and Germany. R and $\mathrm{D}$ in dairy science largely refers to dairy goat breeds, but developing countries also have to deal with dual- and triple purpose breed

- Interdisciplinary approaches that address demographics, socioeconomics, resource allocation, value chains, trade and marketing, and self-reliance will be very useful.

These awesome details emphasize how important it is to seek the highest efficiency in the use of the natural resources to the extent possible. Maximizing the contribution from goats is just one example of how they can be used as an entry point for the development of the LFAs. The real question is whether systems orientation and effective development policy can directly improve sustainable food production 
Citation: Devendra C (2015) Goats: Imperatives for Developing the Champions of the Poor and the Landless. Agrotechnol 4: e113. doi:

Page 3 of 3

and environmental protection for small farmers and the landless who own goats, and whose enduring hope is of secure and sustained food supplies from - animal agriculture .The goal of technologically driven transformation is our collective responsibility and in the long term, hopefully the vision for the future is sustained food supplies from animal agriculture, decreased poverty, significantly improved livelihoods and self-reliance in the immediate future.

Agriculture is under pressure to change from traditional structures to globalization, and in these circumstances direct assertive development is essential.. For the poor and the marginalized, the enduring dream for the future is a world where there is a peaceful agricultural countryside, where natural resources are environmentally sustainable, where there is no poverty and starvation, innovation and self-reliance are vital, and the agricultural landscape is in harmony with nature. These goals are achievable, but resourceful innovation and vision must lead the way in the future.

Let me end by echoing an adaptation from an excellent Ethiopian proverb as follows:-

"Rainfed land rich in goats is never poor and land poor in goats is never rich"

\section{References}

1. Devendra C (1999) Small ruminant production systems in semi-arid and arid environments Annals of Arid Zone 37: 215-232.
2. Iniguez L (2010) The challenges of research and development of small ruminant production in dry areas. Small Ruminant Research 98: 9-20.

3. Devendra C (2007) Goats: Biology, production and development in Asia. Academy of Sciences Malaysia, Kuala Lumpur, Malaysia.

4. Devendra C (2014a) The search for efficiency in the management of natural resources. Outlook on Agriculture 43: 1-12

5. Devendra C (2014b) Perspectives on the Potential of Silvopastor Systems.

6. Agrotechnology 3: 117. doi:10.4172/2168-9881.1000117

7. Devendra C (1987) Herbivores in the arid and the wet tropics. In The Nutrition of Herbivores. Proceedings of the 2nd International Symposium on the Nutrition of Herbivores, Australia: 23-46

8. Devendra C (2014c) Gender equity in sustainable animal -agriculture enhancing Tempowerment and The contribution of women for improved livelihoods, stable households and rural growth. Proceedings 2nd AsianAustralasian Dairy Goat Conference, Bogor, Indonesia: 21-30

9. 8.Devendra C (2014d) Transforming agricultural education, technological improvement for enhancing productivity growth and prosperity in Asia Shared vision for strengthening Asia-Africa linkages. In: Towards impact and resilience: transformative change in and through agricultural education and training in Sub-Saharan Africa, (Eds.F.Swanapoel, Z.Ofir and A.Stroebel), Cambridge Scholars Press. U.K., pp. 90-114. "Cambridge Scholars Press, UK: 90-114. 